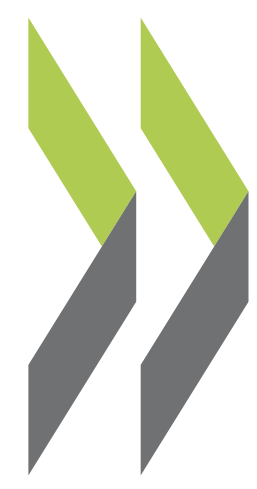

OECD Economics Department Working Papers No. 946

Assessing the Sensitivity of Hungarian Debt Sustainability to Macroeconomic Shocks Pierre Beynet, under Two Fiscal Policy Reactions 
Organisation de Coopération et de Développement Économiques

Organisation for Economic Co-operation and Development

09-Mar-2012

ECONOMICS DEPARTMENT

English - Or. English

\begin{abstract}
ASSESSING THE SENSITIVITY OF HUNGARIAN DEBT SUSTAINABILITY TO
MACROECONOMIC SHOCKS UNDER TWO FISCAL POLICY REACTIONS
\end{abstract}

ECONOMICS DEPARTMENT WORKING PAPERS No. 946

by Pierre Beynet and Edouard Paviot

All Economics Department Working Papers are now available through OECD's Internet Website at http://www.oecd.org/eco/workingpapers

JT03317494

Complete document available on OLIS in its original format

This document and any map included herein are without prejudice to the status of or sovereignty over any territory, to the delimitation of international frontiers and boundaries and to the name of any territory, city or area. 


\section{ABSTRACT/RESUMÉ \\ Assessing the sensitivity of Hungarian debt sustainability to macroeconomic shocks under two fiscal policy reactions}

Hungarian debt level has steadily increased since 2001, with the debt-to-GDP ratio reaching about 84\% at end-2011. This high level combined with significant volatility of macroeconomic variable influencing potential future debt paths GDP growth, exchange rate and interest spreads - put Hungarian debt sustainability at risk. To assess debt sustainability over a 5-year horizon, a stochastic debt simulation has been conducted by applying random shocks derived from historical volatility to a baseline scenario. These simulations are used to derive fan charts showing the distribution probability of debt under different sets of assumptions regarding i) the nature of shocks - temporary or permanent - and ii) fiscal policy reactions, i.e. either allowing automatic stabilizers to operate or not. Results indicate that the probability of a debt ratio going beyond 90\% of GDP in the next five years - a level beyond which debt is likely to hurt growth - is non-negligible (at least $25 \%$ in the most favourable scenario), especially if volatility turns out to be higher than observed in the past. The main risks to debt sustainability lie in growth shocks, whose volatility is high in Hungary. This highlights the crucial role of growth for debt sustainability. The impact of exchange rate depreciation can also be important, especially if shocks are permanent, while the rise in interest spreads would have a much more limited impact as debt is only progressively rolled over. Finally, fiscal policy reaction matters. Offsetting the impact of automatic stabilizers significantly reduces the width of potential debt paths over the five-year horizons.

This Working Paper relates to the 2012 OECD Economic Survey of Hungary (www.oecd.org/eco/surveys/hungary).

JEL classification: H62, H63, C15, E62

Keywords: Hungary; public debt sustainability; risk analysis; fan charts; fiscal reaction function

$* * * * * * * * * * * *$

\section{Évaluer la sensibilité de la viabilité de la dette publique hongroise aux chocs macroéconomiques selon de deux réactions de politique budgétaire}

La dette de la Hongrie n'a cessé de s’accroître depuis 2001 et le ratio de dette sur PIB a atteint environ 84 \% fin 2011. Ce niveau élevé, conjugué à la grande volatilité de variables macroéconomiques influant sur les profils possibles d'évolution de la dette à l'avenir - croissance du PIB, taux de change et écarts de taux d'intérêt - hypothèquent la viabilité de la dette publique hongroise. Pour évaluer la viabilité de la dette sur un horizon de cinq ans, une simulation stochastique a été effectuée, dans laquelle des chocs aléatoires basés sur la volatilité historique de la dette ont été appliqués à un scénario de référence. À partir de ces simulations, des graphiques ont été construits en éventail illustrant les évolutions probables de la dette en fonction de différentes hypothèses relatives i) à la nature des chocs - temporaires ou permanents - et ii) à la réaction de la politique budgétaire, à savoir, laisser ou non opérer les stabilisateurs automatiques. Les résultats font apparaître une probabilité non négligeable (d'au moins $25 \%$ dans le scénario le plus favorable) que le ratio dette/PIB dépasse $90 \%$ - niveau au-delà duquel l'endettement risque d'entraver la croissance - d'ici cinq ans, surtout si les paramètres étudiés se révèlent plus instables encore que par le passé. Les principaux risques qui pèsent sur la viabilité de la dette résident dans l'évolution de la croissance, laquelle affiche une forte volatilité en Hongrie. Il apparaît donc que la croissance joue un rôle déterminant dans la viabilité de la dette. L'incidence d'une dépréciation du taux de change peut également être importante, notamment si ce choc est permanent, alors que l'augmentation des écarts de taux d'intérêt aurait un effet bien moindre, du fait du refinancement progressif de la dette. Enfin, la réaction de la politique budgétaire a, elle aussi, son importance. En compensant l'impact des stabilisateurs automatiques, on réduit sensiblement l'éventail des trajectoires envisageables de la dette sur un horizon de cinq ans.

Ce Document de travail se rapporte à l’Étude économique de l’OCDE de la Hongrie, 2012 (www.oecd.org/eco/etudes/hongrie).

Classification JEL: H62, H63, C15, E62

Mots-clés: Hongrie; viabilité de la dette publique; analyse de risques ; graphiques en éventail ; fonctions de réaction budgétaires

(c) OECD (2012)

You can copy, download or print OECD content for your own use, and you can include excerpts from OECD publications, databases and multimedia products in your own documents, presentations, blogs, websites and teaching materials, provided that suitable acknowledgment of OECD as source and copyright owner is given. All requests for commercial use and translation rights should be submitted torights@oecd.org. 


\section{TABLE OF CONTENTS}

Assessing the sensitivity of hungarian debt sustainability to macroeconomic shocks under two fiscal policy

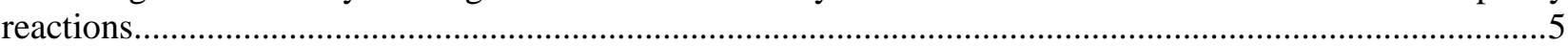

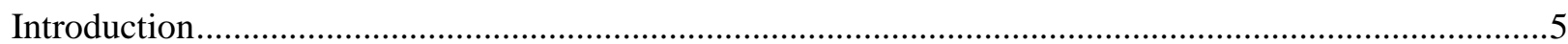

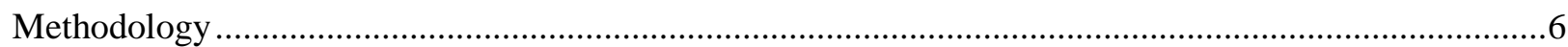

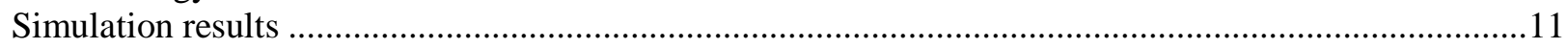

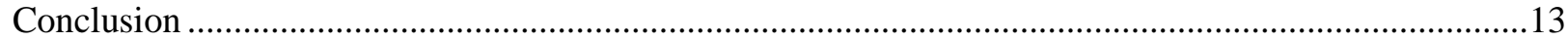

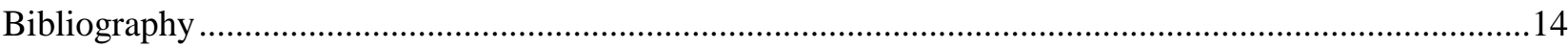

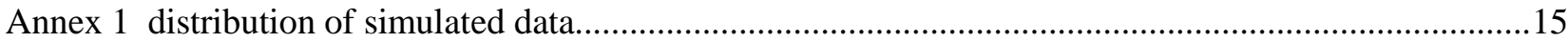

\section{Tables}

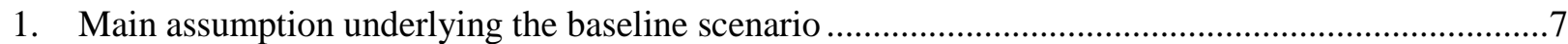

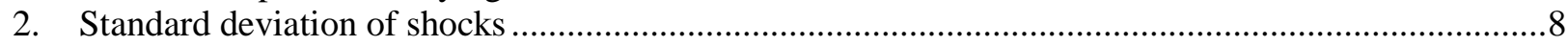

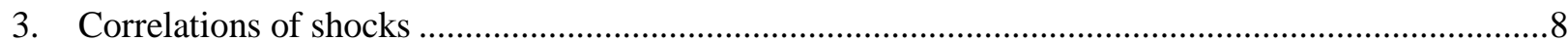

\section{Figures}

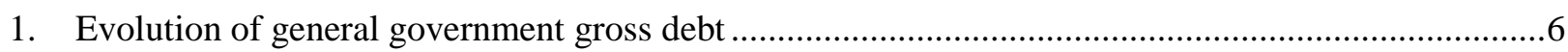

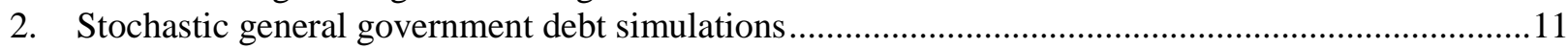

3. Impact of shocks on each variable separately on general government debt shock simulations ..........12 
ECO/WKP(2012)23 
ECO/WKP(2012)23

\title{
ASSESSING THE SENSITIVITY OF HUNGARIAN DEBT SUSTAINABILITY TO MACROECONOMIC SHOCKS UNDER TWO FISCAL POLICY REACTIONS
}

\author{
by Pierre Beynet and Edouard Paviot ${ }^{1}$
}

\section{Introduction}

Hungarian public debt has steadily increased since 2001, from 53\% of GDP to about 84\% of GDP at end-2011 (OECD, 2011). The increase in the debt ratio reflects mainly fiscal deficits but also temporary and permanent shocks to the economy, such as changes in nominal GDP, interest payments, and exchange rates. As around half of Hungarian debt was denominated in foreign currency at end-2011, the debt ratio is particularly sensitive to fluctuations in exchange rates.

The Hungarian fiscal framework specifies that the debt-to-GDP ratio should decline over time. The debt rule adopted in the fiscal responsibility law of 2008 specified that the budget should be consistent with a debt-to-GDP ratio constant in real term, i.e. a debt ratio declining at the speed of real GDP growth (OECD, 2009). In Spring 2011, the government adopted a new constitutional debt rule stipulating that gross public debt should eventually be cut below 50\% of GDP, backed by the requirement that the budget be consistent with a reduction in the debt ratio each year, as long as it is above the target level. A cardinal law adopted in late December 2011, which repealed the law on fiscal responsibility, specified that public debt can increase only by expected inflation minus half of expected real GDP growth from 2016 onwards.

In practice, whether a debt-to-GDP ratio will follow a declining path is highly dependent on unexpected shocks affecting the economy (Chalk and Hemming, 2000). To analyse the potential impact of such shocks, an analysis of potential debt paths subject to macro-economic shocks has been conducted using random shocks drawn from the variance of historical shocks. This allows fan charts to be constructed illustrating the most likely debt paths for the next years. These fan charts are then used to analyse the impact of different sets of assumptions: $i$ ) whether macro-economic shocks are temporary or permanent, and ii) whether fiscal policy allows the automatic stabilizers to operate or not.

While the two fiscal reaction scenarios envisaged are simple, they are likely to encompass fiscal policy options in the coming years, as the sovereign debt crisis is likely to limit policy choices. Recent downgrades of Hungarian debt and some failed debt auctions towards end-2011 and early 2012 highlighted limited fiscal policy space: ensuring the credibility of fiscal policy will most likely require sticking to the medium-term fiscal targets, even in the event of unforeseen macro-economic shocks, allowing at best the automatic stabilisers to operate.

1. The authors are respectively member of the Economics Department of the OECD and former OECD external consultant. They authors are grateful to Stéphane Sorbe, Bob Ford, Rafal Kierzenkowski and other colleagues from the OECD for valuable comments and suggestions. They would like to thank Desney Erb for excellent statistical assistance. 


\section{Methodology}

The methodology used to run stochastic debt simulations follows Di Giovanni and Edward (2008). This methodology is a simplified version of more sophisticated stochastic methods to analyze debt sustainability, such as those by Celasun, Debrun and Ostry (2006). Instead of directly simulating stochastic debt paths, the methodology builds confidence intervals around a baseline scenario by applying random shocks to the debt accumulation equation. The main differences from Di Giovanni and Edward (2008) lie in the introduction of random shocks to the exchange rate, the comparison between two alternative fiscal policy reactions, and feedback on activity of changes in the fiscal balance related to automatic stabilizers. This paper also analyzes the impact of each variable shock separately. The projections of the debt paths are limited to 5 years since projecting beyond 5 years would give increasingly unlikely debt paths owing to the relatively simple macro-economic projections and fiscal policy alternative assumed here.

The baseline scenario is derived from the OECD Economic Outlook 90 until 2013. From 2014 onwards, underlying macro-economic projections follows the OECD medium-term analysis (see below). In addition, it is assumed that the fiscal primary balance from 2014 onwards is consistent with a proposal by the European Commission that the debt ratio declines by $1 / 20^{\text {th }}$ each year as long as it is above $60 \%$ of GDP. The rule suggested by the European Commission is consistent with the Hungarian requirement that the debt ratio should be declining as long as it is over 50\% of GDP. The debt ratio is defined as the Maastricht debt. It should be noted that the baseline scenario based on the European Commission proposal is quite ambitious since it implies that the debt-to-GDP ratio decreases by about 1.2 p.p. per year on average over 2014-2016, which would be quite a dramatic turnaround compared to the 2002-11 period, when the debt ratio increased on average by 3.2 p.p. per year. The figure below shows the evolution of debt from 2001 and the baseline scenario from 2012 to 2016.

Figure 1. Evolution of general government gross debt

Maastricht definition, per cent of GDP

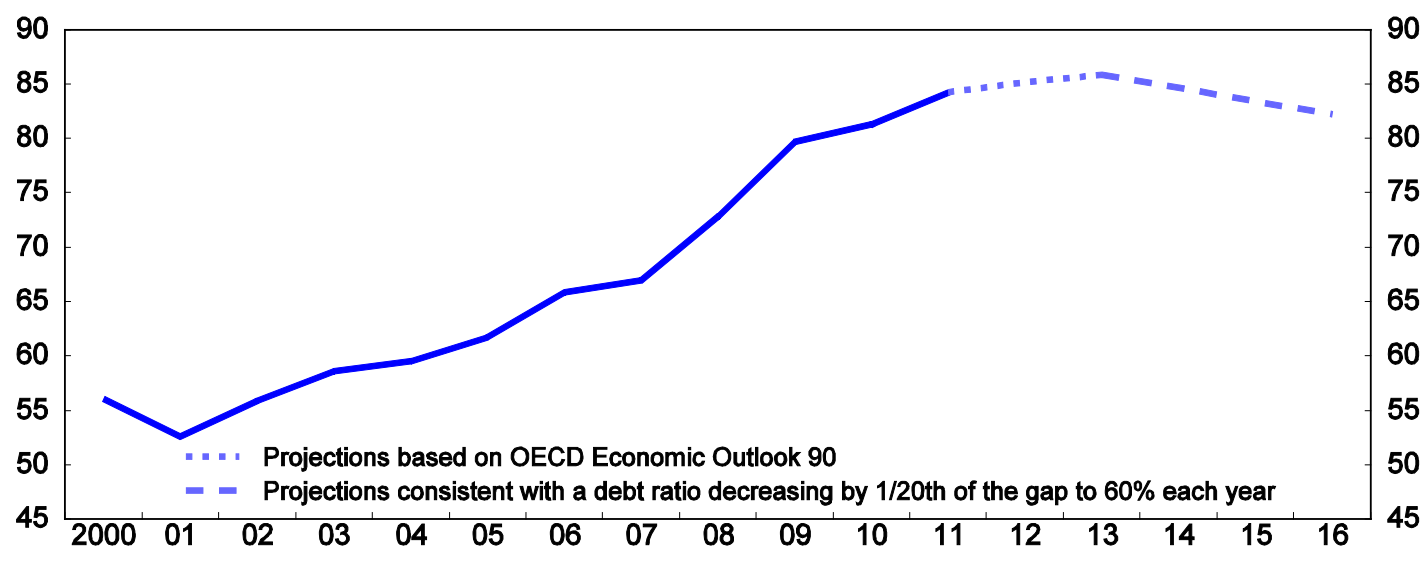

Source: OECD (2011), OECD Economic Outlook: Statistics and Projections (database), December and OECD calculations. 
The baseline scenario follows OECD medium-term projections. This medium-term scenario is built around a potential growth estimate based on OECD methodology and assumes that the output gap has mostly closed within five years with GDP growth converging towards potential GDP (OECD, 2012). As a result, real GDP growth projections from 2014 to 2016 are above potential GDP. The GDP deflator is assumed to converge to the central bank inflation target of 3\% from 2014 onwards. Interest rates of the different currencies are based on the most recent available data and kept constant. Since almost all debt in foreign currency is swapped into euros, debt in foreign currency is assumed to be in euro only. Finally, the primary balance is projected from 2014 onwards so as to ensure a decline of the debt ratio by $1 / 20^{\text {th }}$ of the gap to $60 \%$ each year, as explained above. The table below summarizes the value of the main variables (GDP growth, inflation, primary fiscal balance, interest rate on debt) of the baseline scenario.

Table 1. Main assumption underlying the baseline scenario

\begin{tabular}{ccccccc}
\hline & $\begin{array}{c}\text { Real GDP } \\
\text { growth }\end{array}$ & $\begin{array}{c}\text { Inflation } \\
\text { (GDP } \\
\text { deflator) }\end{array}$ & $\begin{array}{c}\text { Primary } \\
\text { balance (in } \\
\text { \% of GDP) }\end{array}$ & $\begin{array}{c}\text { Average } \\
\text { interest rate } \\
\text { on debt }\end{array}$ & $\begin{array}{c}\text { Of which: } \\
\text { interest rate } \\
\text { on debt in } \\
\text { HUF }\end{array}$ & $\begin{array}{c}\text { Of which: } \\
\text { interest rate } \\
\text { on debt in } \\
\text { EUR }\end{array}$ \\
\cline { 2 - 6 } 2011 & 1.5 & 2.0 & 7.9 & 5.3 & & \\
2012 & -0.6 & 4.0 & 0.7 & 5.4 & 6.4 & 4.8 \\
2013 & 1.2 & 2.4 & 0.9 & 5.6 & 6.4 & 4.8 \\
2014 & 2.5 & 3.0 & 1.4 & 5.6 & 6.4 & 4.8 \\
2015 & 2.4 & 3.0 & 1.4 & 5.6 & 6.4 & 4.8 \\
2016 & 2.4 & 3.0 & 1.3 & 5.6 & 6.4 & 4.8 \\
\hline
\end{tabular}

Source: OECD (2011), OECD Economic Outlook: Statistics and Projections (database), December, OECD (2012), Long-Term economic growth, forthcoming WP1 paper; Thomson (Datastream).

The stochastic confidence intervals around the baseline scenario are determined by applying random shocks to the debt accumulation equation. The shocks are derived from the variance-covariance matrix of shocks of the last ten years (i.e. 2002-11). The implicit assumption is that the volatility of macro-economic variables during the simulation period (next five years) will be similar to the volatility observed in the last 10 years. While the 2002-11 period incorporates one episode of high financial stress (2009), volatility in the next 5-year could in practice be higher than observed in the past. Each shock is constructed as the first difference of the quarterly variable $\mathrm{x}$ :

$$
\varepsilon_{q}^{x}=x_{q}-x_{q-1}
$$

Table 2 summarizes the volatility of shocks over the period 2002-11. The volatility of shocks is very high for nominal GDP, with an annualized standard deviation almost identical to average (annual) nominal growth, both because of high real GDP and price volatility. Annualized volatility is less marked for the interest rate, being the strongest for EUR and the weakest for HUF. It should be noted that interest rates in forint and euro are those of Hungarian bonds in the secondary markets and, hence, incorporate spreads. Interest rates of forint are those of a 5-year maturity bond and those in Euros of a 10 years maturity bond, since they are close to the average maturity of Hungarian public debt in each of these currencies. Finally, exchange rate demonstrates the weakest volatility compared to average value. 
Table 2. Standard deviation of shocks

2002-11

\begin{tabular}{lccc}
\hline & $\begin{array}{c}\text { Standard deviation } \\
\text { of shocks (quarterly) }\end{array}$ & $\begin{array}{c}\text { Standard deviation } \\
\text { of shocks } \text { (annualized) }^{\text {(andine value }}\end{array}$ & $\begin{array}{c}\text { Average variables (annual) } \\
\text { of valu }\end{array}$ \\
\hline Nominal GDP growth & 3.03 & 6.05 & 7.03 \\
Interest rate in HUF & 1.00 & 2.00 & 7.77 \\
Interest rate in EUR & 0.85 & 1.71 & 4.62 \\
Exchange rate (1 EUR = n HUF) & 14.32 & 28.60 & 259 \\
\hline
\end{tabular}

1. Annualized standard deviations of shocks are assumed to be twice as big as quarterly deviations. Source: OECD calculations based on OECD (2011), OECD Economic Outlook: Statistics and Projections (database) and Thomson (Datastream).

The correlation between different variables is consistent with what can be expected based on stylized facts or intuition. Shocks to interest rates are negatively (and weakly) correlated to shocks to Hungarian growth. This is also true of the interest rate in euro, most likely reflecting the high correlation between the interest rates in forint and euro (which is consistent with the fact that interest rates in euros are those of Hungarian bonds in the secondary market) but also the high leverage in foreign currency of the Hungarian economy. Shocks to exchange rate have no impact on nominal growth, which is likely to be related to a delayed impact on activity of exchange rate variations. Finally, shocks to HUF or EUR interest rate and EUR/HUF exchange rate are highly correlated. The sign of the correlation indicates that a positive change in interest rates is correlated with currency depreciation, which may seem counter-intuitive. In fact, the explanation is that shocks to interest rate are essentially driven by spreads, which are positively correlated with exchange rate. For example, a period of financial stress leads to a simultaneous rise in spreads and depreciation of the exchange rate.

Table 3. Correlations of shocks

2002-11

\begin{tabular}{lcccc}
\hline & Growth & Interest rate in HUF & Interest rate in EUR & EUR/HUF exchange rate \\
\hline Growth & 1 & $\ldots$ & $\ldots$ & $\ldots$ \\
Interest rate in HUF & -0.14 & 1 & $\ldots$ & $\ldots$ \\
Interest rate in EUR & -0.15 & 0.48 & 1 & $\ldots$ \\
EUR/HUF exchange rate & -0.02 & 0.50 & 0.52 & 1 \\
\hline $\begin{array}{l}\text { Source: OECD calculations based on OECD (2011), OECD Economic Outlook: Statistics and Projections (database) and Thomson } \\
\text { (Datastream). }\end{array}$
\end{tabular}

The Monte Carlo simulation is done through the following steps. First, a random vector of quarterly shocks is drawn over 2012-16. These shocks are jointly-normally distributed with means zero and a variance/covariance matrix identical to those of historical shocks. Second, these shocks are added to get annual innovation to the respective variable: growth, interest rates in the two currencies (HUF and EUR) and exchange rate (Annex 1 gives the distribution of simulated variables). The annual shocks on the different variables are written in the following way:

- Growth shock of year t: the annual shock is the sum of quarterly shocks, hence:

$$
\varepsilon_{t}^{g}=\sum_{q=1}^{4} \varepsilon_{q, t}^{g}
$$


- Exchange rate shocks are similarly the sum of quarterly shocks:

$$
\varepsilon_{t}^{e}=\sum_{q=1}^{4} \varepsilon_{q, t}^{e}
$$

- Shocks to interest rates of the different currencies are getting bigger overtime as debt is progressively rolled over. It is assumed that all debt has been issued at fixed interest rates, so a shock on interest rates in a given year is carried over to the following years proportionally to the part of the debt that has been rolled over. Shocks to the interest rate are applied assuming an average maturity of debt in domestic currency and foreign currency (euro) of, respectively, 5 and 10 years. Hence, the value of the shocks from years 2012 to 2016 are the following:

$$
\varepsilon_{t}^{r}=\frac{1}{T} \sum_{y=2012}^{t} \sum_{q=1}^{4} \varepsilon_{q, y}^{r} \text { with } \mathrm{T}=5 \text { for HUF and } \mathrm{T}=10 \text { for euros }
$$

These shocks are applied to the debt accumulation equation in two different ways. The first is to assume temporary shocks: new shocks only impact the baseline variable each year; the implicit assumption being that the impact of past shocks on the different variables is not persistent. The second way to apply shocks is to assume that past shocks are persistent, i.e. that new shocks impact the last value of the variable, not the baseline assumption. This assumption of a permanent impact of shocks (i.e. a persistence of past shocks) is applied only to interest and exchange rates. Permanent shocks on exchange rates are expressed in percentage and not in level so as to keep the relative size of shocks identical when the exchange rate deviates from the baseline level. Shocks to GDP are assumed to remain temporary. Obviously, these two scenarios are extreme cases, and the most likely debt paths are probably in between these two scenarios. The way shocks are simulated is:

- Temporary shocks:

$$
\begin{aligned}
g_{t} & =\overline{g_{t}}+\varepsilon_{t}^{g} \text {, with } \overline{g_{t}} \text { being the baseline value } \\
r_{t} & =\bar{r}_{t}+\varepsilon_{t}^{r} \text {, with } \bar{r}_{t} \text { being the baseline value } \\
e_{t} & =\bar{e}_{t}+\varepsilon_{t}^{e} \text {, with } \overline{e_{t}} \text { being the baseline value }
\end{aligned}
$$

- Permanent shocks:

$$
\begin{gathered}
r_{t}=r_{t-1}+\varepsilon_{t}^{r} \text { if } \mathrm{t} \geq 2013 \\
e_{t}=e_{t-1} \times\left(1+\varepsilon_{t}^{\prime e}\right) \text { if } \mathrm{t} \geq 2013 \text {, with } \varepsilon_{t}^{\prime e}=\frac{e_{t}-e_{t-1}}{e_{t-1}}
\end{gathered}
$$

More sophisticated models of stochastic debt simulation usually assume a fiscal policy reaction function to increase the likelihood of the simulated debt path. In this simple stochastic debt sustainability exercise, no fiscal policy reaction function has been estimated. However, two different simple fiscal policy reactions are tested: the first allows the automatic stabilizers to operate; the second offsets them. Assuming that average tax elasticity to GDP is equal to one, letting the automatic stabilisers operate is equivalent to assuming that changes in the fiscal balance (in percent of GDP) are approximately equal to changes in the output gap (in percent of GDP) times the tax burden (in percent of GDP). 


$$
\begin{aligned}
& \Delta(\text { fiscalbalance }) \approx \frac{\text { Taxes }}{G D P} \Delta(\text { outputgap }) \\
& \text { Or: } \varepsilon_{t}^{p}=0.36 \times \varepsilon_{t}^{g}
\end{aligned}
$$

Letting the automatic stabilizers operate has a feedback on activity through fiscal multipliers. The fiscal multipliers are derived from S. Benk and Z. Jakab (2012), taking into account their estimates of tax multipliers since it is assumed that automatic stabilizers mainly operate on the revenue side. Using a weighted average of the elasticity of three main taxes (labour income taxes, social contribution and valued-added) based on their respective share in total revenues collected, we obtain:

$$
\Delta(\text { outputgap }) \approx-0.2 \times \Delta(\text { fiscalbalance })
$$

Starting from the debt ratio in 2011, we apply the different shocks to the debt accumulation equation to obtain debt paths over 2012-21. We repeat the above steps 100 times and extract the $5^{\text {th }}, 25^{\text {th }}$, $75^{\text {th }}$ and $95^{\text {th }}$ percentile to construct a fan chart of the debt path. The debt accumulation equation is obtained by summing up the debt accumulation equation for the debt in each currency, assuming that primary deficits are financed in each of the two currencies (HUF and USD) proportionally to the ratio of the debt in each currency in 2011. The debt accumulation equation is obtained in the following way:

Debt level in HUF:

$$
D_{t}^{H U F}=\left(1+r^{H U F}\right) \times D_{t-1}^{H U F}-\frac{D_{2011}^{H U F}}{D_{2011}^{\text {Total }}} \times P_{t}
$$

Debt level in EUR:

$$
D_{t}^{E U R}=\left(1+r^{E U R}\right) \times D_{t-1}^{E U R}-\frac{e_{2011}^{H U F / E U R} \times D_{2011}^{E U R}}{D_{2011}^{\text {Total }}} \times \frac{P_{t}}{e_{t}^{H U F / E U R}}
$$

Total debt level in HUF:

$$
D_{t}^{\text {Total }}=D_{t}^{H U F}+e_{t}^{H U F / E U R} \times D_{t}^{E U R}
$$

Or, by inserting (1) and (2) into (3):

$$
D_{t}^{\text {Total }}=\left(1+r_{t}^{\text {HUF }}\right) \times D_{t-1}^{H U F}+e_{t}^{H U F / E U R} \times\left(1+r_{t}^{\text {EUR }}\right) \times D_{t-1}^{\text {EUR }}-P_{t}
$$

Finally, by dividing all variable by GDP and using lower cases for ratio to GDP:

$$
d_{t}^{\text {Total }}=\frac{1+r_{t}^{\text {HUF }}}{1+g_{t}} \times d_{t-1}^{\text {HUF }}+\frac{e_{t}^{\text {HUF } / \text { EUR }}}{e_{t-1}^{\text {HUF } / E U R}} \times \frac{1+r_{t}^{\text {EUR }}}{1+g_{t}} \times d_{t-1}^{\text {EUR }}-p_{t}
$$




\section{Simulation results}

\section{Fan charts of temporary or permanent shocks, depending on fiscal policy reaction}

The stochastic simulations of debt result in different fan charts depending on whether shocks are considered temporary or permanent (Figure 2). Permanent shocks illustrate a more risky scenario. Potential debt paths diverge more substantially depending on whether the automatic stabilizers are allowed to operate. With the automatic stabilizers, the debt path becomes potentially explosive in the worst case (Figure 2, Panel A). Offsetting the impact of automatic stabilizers narrows potential debt trajectories, underscoring the benefits of not deviating excessively from fiscal targets. It should be noted, though, that there is still a probability of 25\% that the debt ratio could be above 90\% of GDP by 2016 (Figure 2, Panel B), a level that is deemed to hurt growth and that may trigger adverse financial market reactions.

Figure 2. Stochastic general government debt simulations ${ }^{1}$

Per cent of GDP

25th-75th percentile

A. With automatic stabilisers

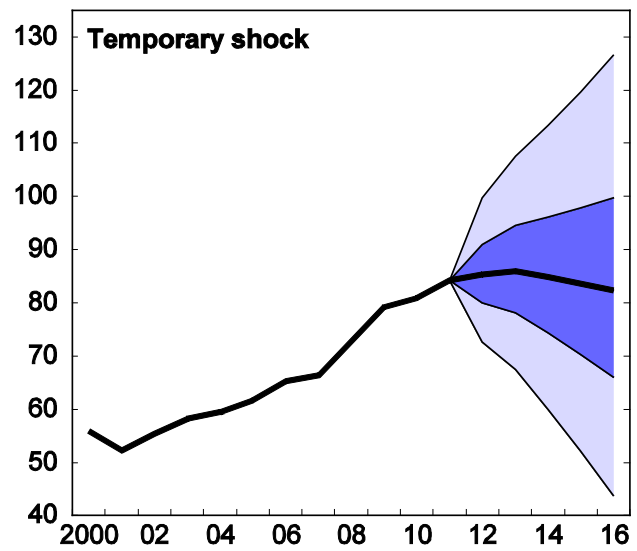

B. Without automatic stabilisers

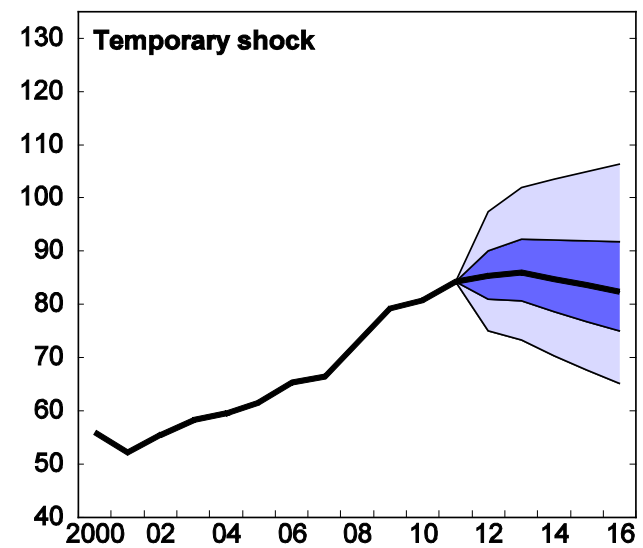

5th-95th percentile $\quad$ Baseline
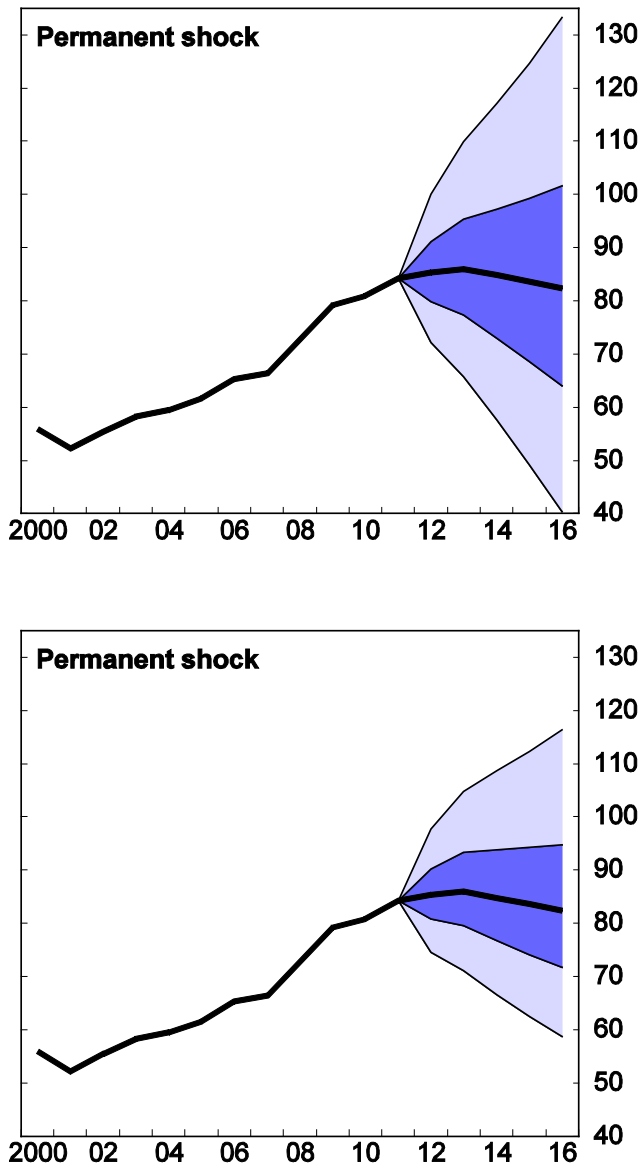

1. The debt path in the baseline scenario follows the debt rule adopted in the fiscal responsibility law of 2009 (i.e. a debt-to-GDP ratio constant in real terms). Temporary and permanent stochastic macroeconomic shocks are applied to the baseline scenario and the likelihood of potential debt paths are shown with their attached probability.

Source: OECD (2011), OECD Economic Outlook: Statistics and Projections (database), December and OECD calculations. 


\section{Impact of isolated shocks}

To analyze the impact of specific shocks on debt, Figure 3 shows the debt path when shocks are applied to each variable independently. Shocks on GDP have the biggest impact, owing to their high volatility and their direct impact on the debt ratio. Shocks on interest rates have the lowest impact, with only one fifth of debt in forint and one tenth of debt in euro being rolled over each year. The impact of exchange rate shocks is in-between. While the volatility of exchange rate is lower than that of other shocks, its impact on debt remains significant since half of the debt has been issued in foreign currency.

Figure 3. Impact of shocks on each variable separately on general government debt shock simulations ${ }^{1}$ Per cent of GDP

A. GDP shock ${ }^{2}$
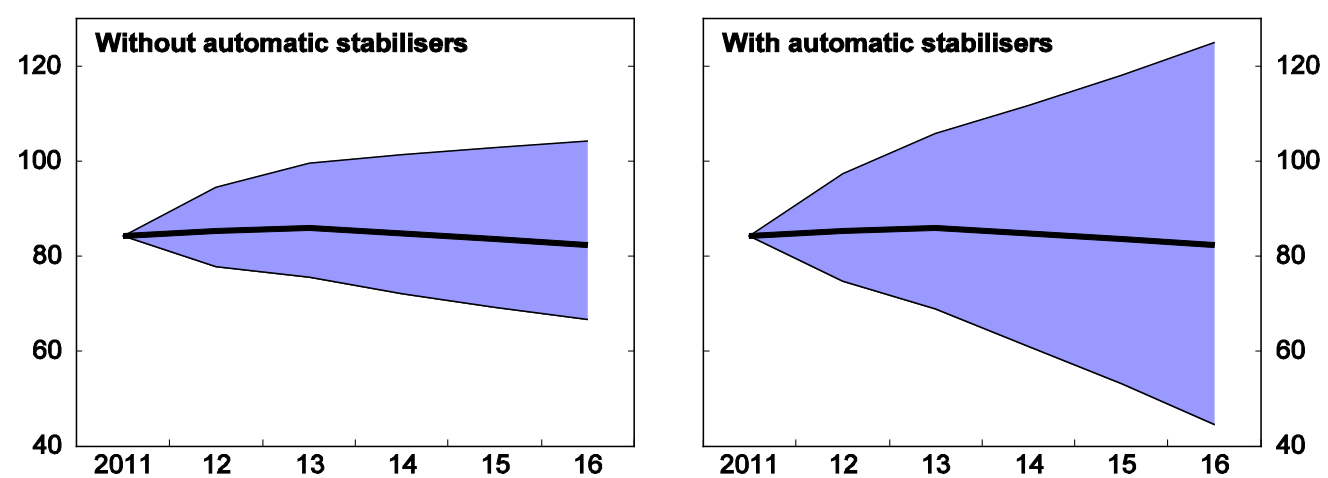

B. Exchange rate shock ${ }^{3}$
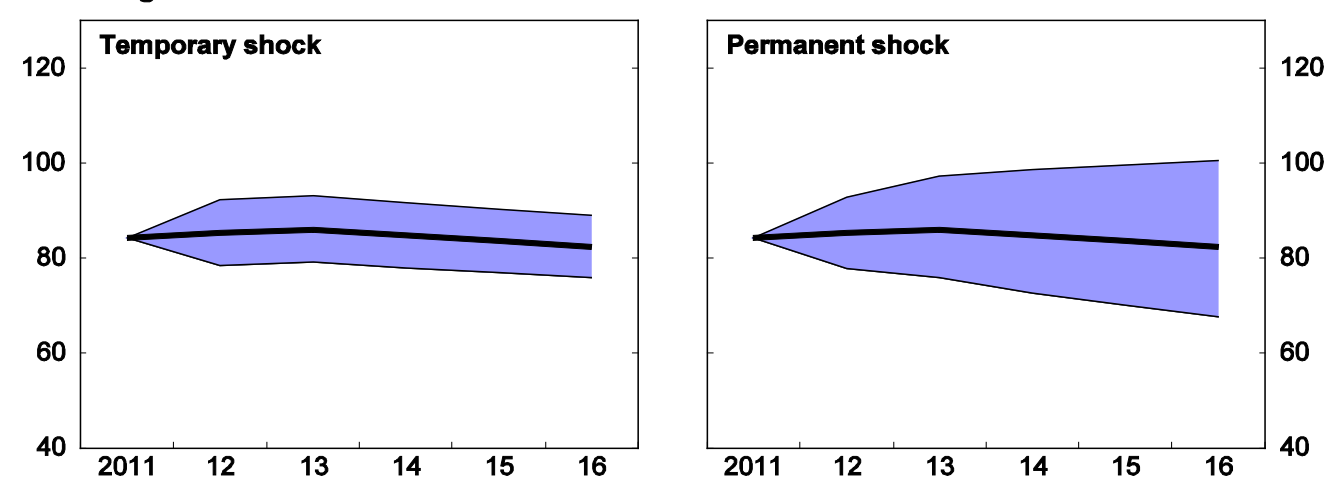

\section{Interest rate shock ${ }^{3}$}
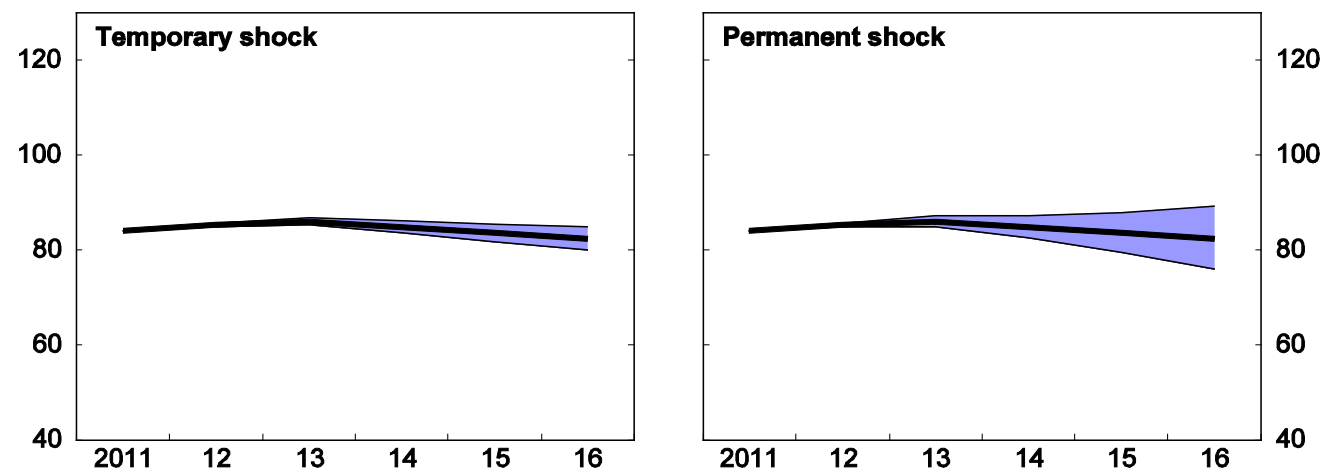

1. Temporary and permanent stochastic macroeconomic shocks are applied to the baseline scenario.

2. No change for temporary or permanent shocks.

3. No change with and without automatic stabilisers.

Source: OECD (2011), OECD Economic Outlook: Statistics and Projections (database), December and OECD calculations. 
Overall, shocks to GDP explain most of the variance: the fan chart resulting from combining all shocks simultaneously is not very different from the one based on GDP shocks only. A back-of-the envelop calculation extracting the standard deviation from the fan charts (assuming that the difference between the 95 percentile and the baseline scenario is roughly equal to the standard deviation) confirms this: the variance of the scenario combining all shocks is close to the sum the variance of each shocks, as it should be the case for normal probability distributions that are roughly additive. This result highlights the crucial role of growth for debt sustainability in Hungary.

\section{Conclusion}

Despite being a simplified version of more sophisticated stochastic debt sustainability analysis, these simulations allow to draw some conclusions on where the risks lie for Hungarian debt sustainability. If the volatility of future shocks remain close to what has been observed in the past 10 years, the probability of a debt ratio going beyond 90\% of GDP in the next five years - a level which is likely to hurt growth - is non-negligible in case of both temporary and permanent shocks (at least $25 \%$ in the most favourable scenario). The main risks to debt sustainability over the 5-year horizon are driven by nominal growth shocks whose volatility is particularly high in Hungary. This highlights the importance of boosting real GDP growth. The impact of exchange rate depreciation on debt sustainability can also be important, especially if shocks are permanent, while the rise in interest spreads would have a much more limited impact over the 5-year horizon. Finally, the fiscal policy reaction matters. Offsetting the impact of automatic stabilizers significantly reduces the width of potential debt path over the five-year horizon compared to a scenario where automatic stabilizers are allowed to operate. 


\section{BIBLIOGRAPHY}

Benk, S. and Z. Jakab (2012), "Non-Keynesian Effects of Fiscal Consolidation: an Analysis with an Estimated DSGE Model for the Hungarian Economy”, OECD Economics Department working paper No. 945.

Chalk, N. and R. Hemming (2000), “Assessing Fiscal Sustainability in Theory and Practice”, IMF Working Paper, WP/00/81, Washington: International Monetary Fund.

Celasun, O., X. Debrun and J. Ostry (2006), "Primary Surplus Behavior and Risks to Fiscal Sustainability in Emerging Market Countries: A “Fan-Chart” Approach”, IMF Working Paper, WP/06/67, Washington: International Monetary Fund.

Di Giovanni, J. and E. Gardner (2008), “A Simple Stochastic Approach to Debt Sustainability Applied to Lebanon”, IMF Working Paper, WP/08/97, Washington: International Monetary Fund.

OECD (2009), OECD Economic Surveys: Hungary 2009, OECD Publishing, Paris.

OECD (2011), OECD Economic Outlook: Statistics and Projections (database), October, Paris.

OECD (2012), “Long-Term Growth Scenarios”, forthcoming OECD Economics Department Working Paper, Paris. 


\section{ANNEX 1}

\section{Distribution of simulated data}

Figures below present histograms of the simulated data to which shocks have been applied (growth, interest and exchange rate) for the 5 years of the projection period.

\section{Distribution of simulated growth}

As expected, the distribution of growth (incl. shocks) is similar over-time. While the distribution is quite wide, it is in line with observed past volatility.

Histogram of g.2012

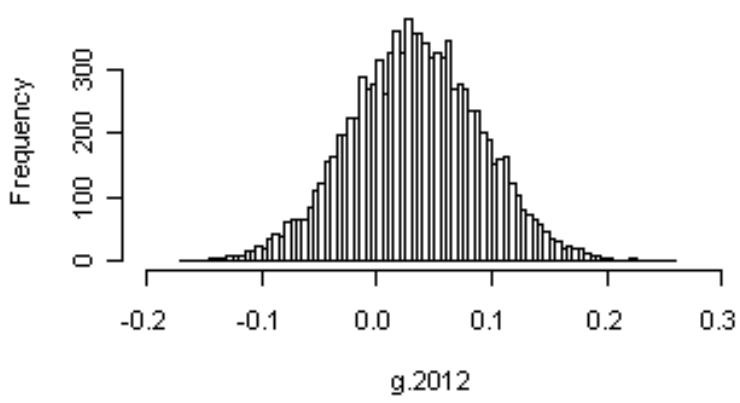

Histogram of g.2014

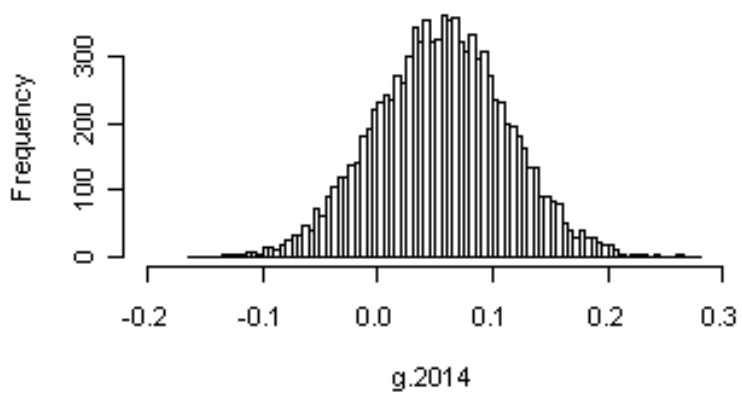

Histogram of g.2016

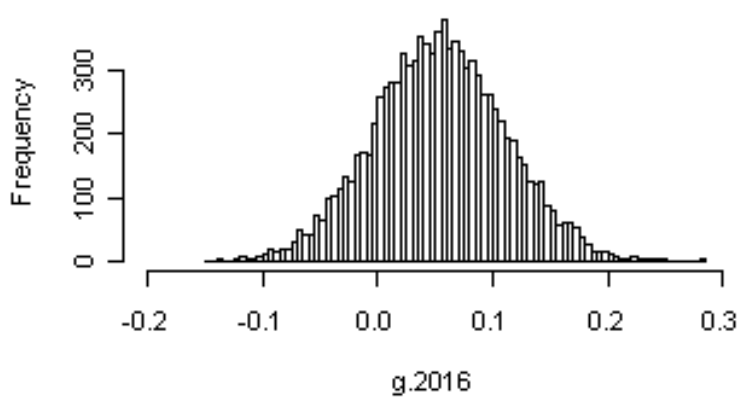

Histogram of g.2013

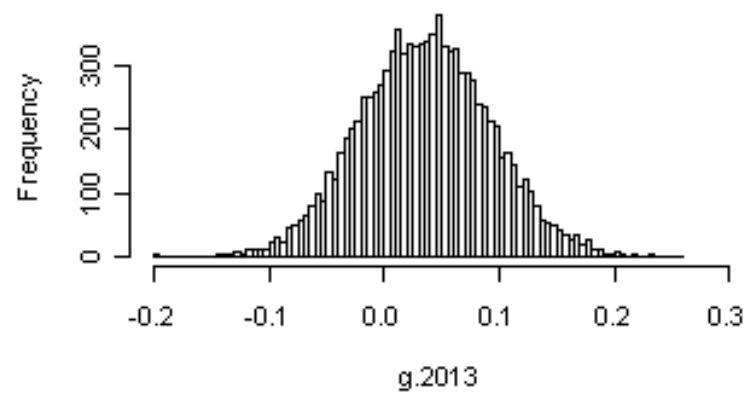

Histogram of g.2015

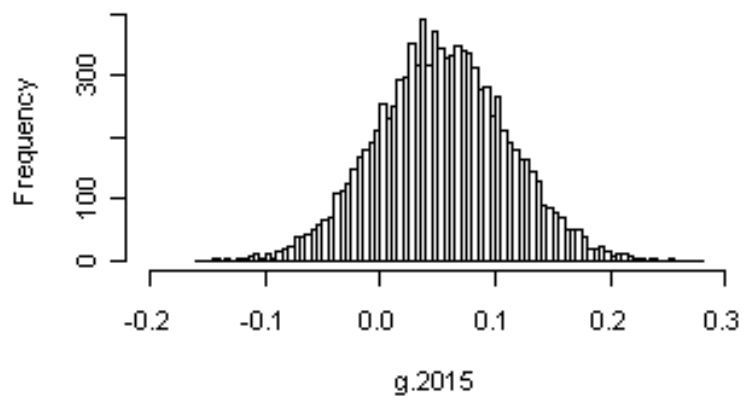


ECO/WKP(2012)23

\section{Distribution of simulated exchange rate}

Temporary shocks

The distribution of exchange rate based on temporary shocks is very similar over-time. The values taken by exchange rate within the $95 \%$ probability are not significantly different from past values.

Histogram of e.2012

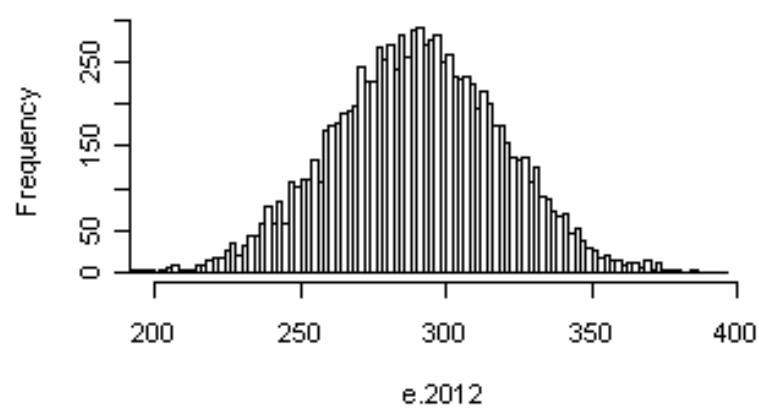

Histogram of e.2014

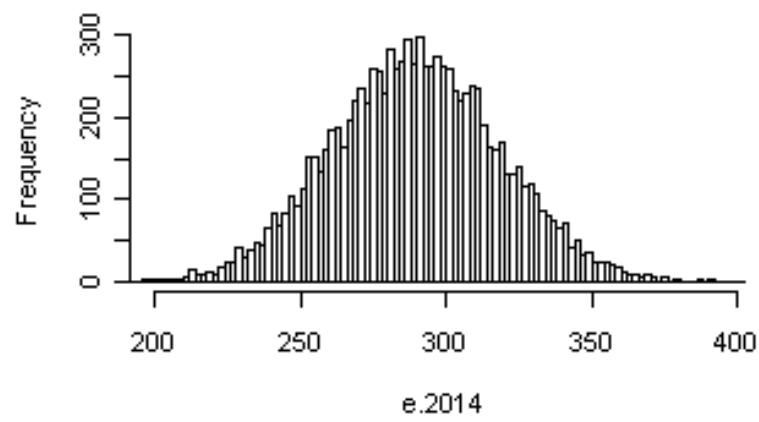

Histogram of e.2016

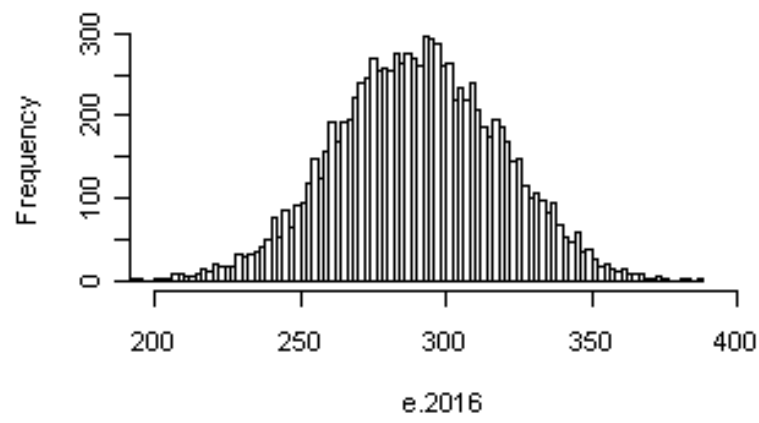

Histogram of e.2013

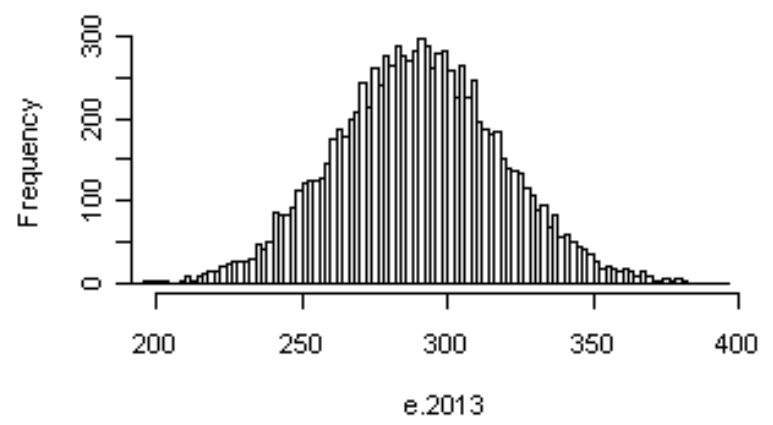

Histogram of e.2015

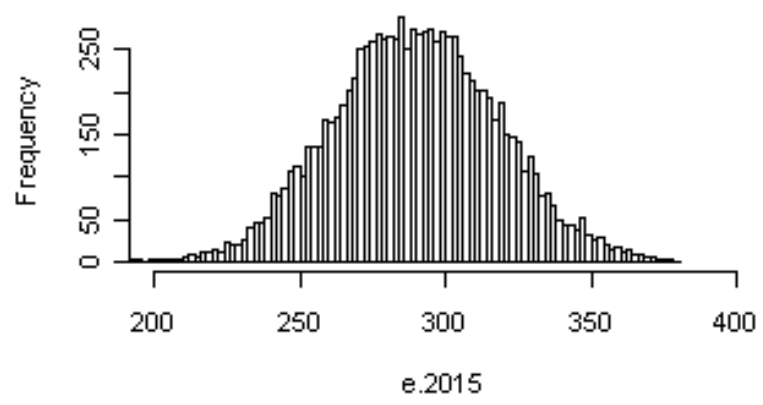




\section{Permanent shocks}

With permanent shocks, the distribution of exchange rate is progressively widening. As shocks are applied in percent and not in level (conversely to temporary shocks), the distribution of simulated exchange rate does not follow a normal law any more. Extreme values taken in the outer years become quite different from historical range of value: they clearly belong to extreme case scenarios.

Histogram of e.2012

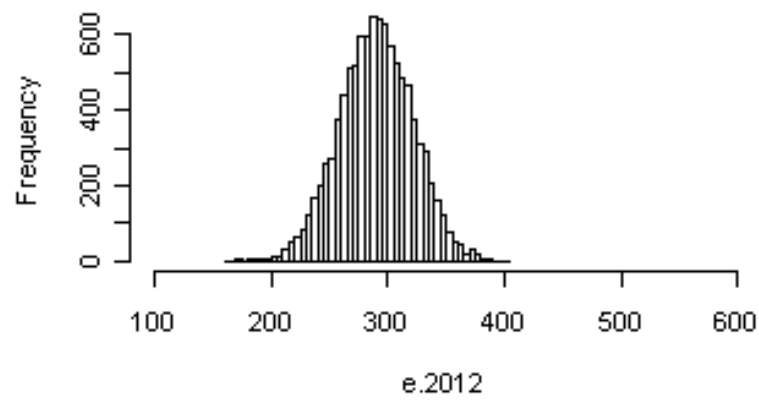

Histogram of e.2014

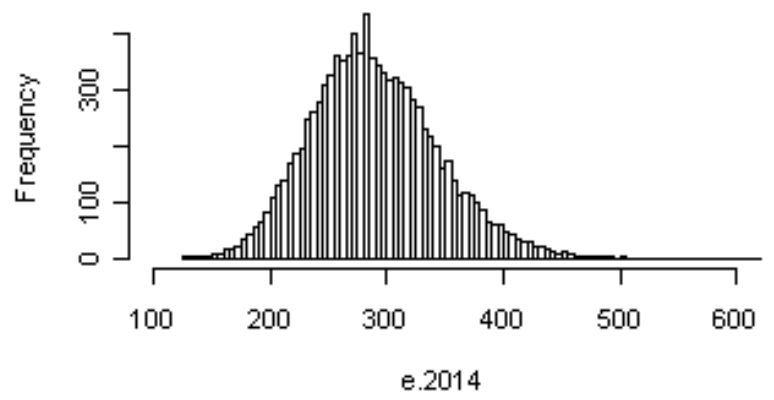

Histogram of e.2016

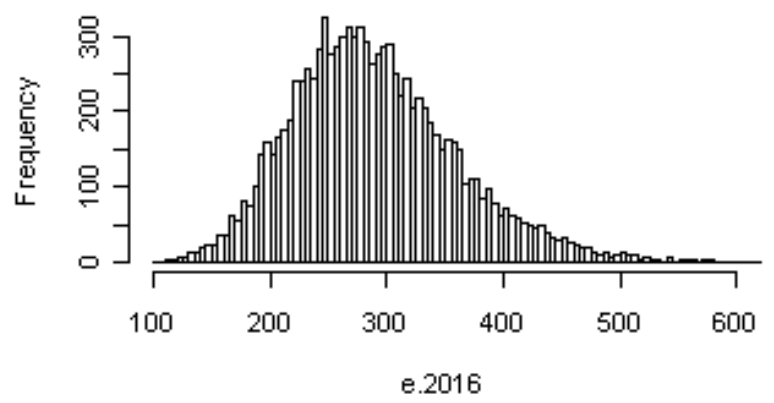

Histogram of e.2013

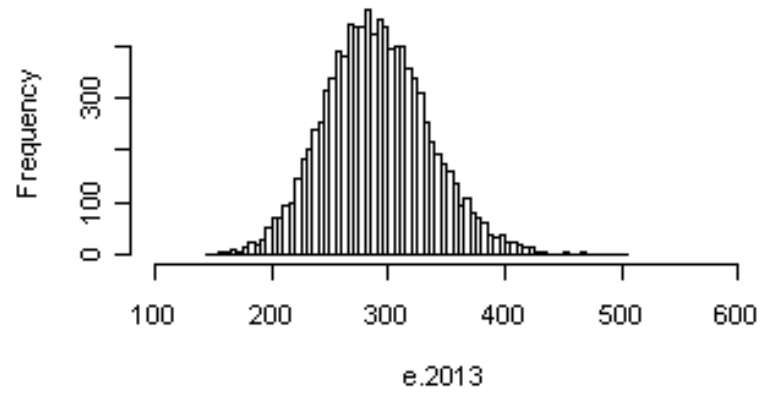

Histogram of e.2015

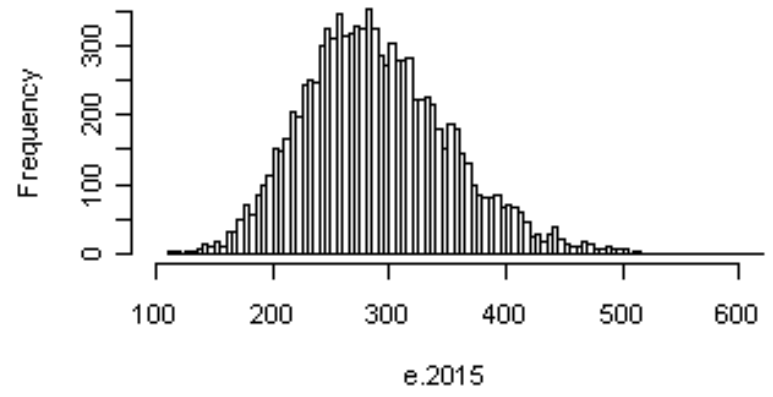




\section{Distribution of interest rates in HUF}

Temporary shocks

The distribution of interest rates in forint is widening slowly because of debt being progressively rolled over: shocks on interest rate fully impact the total amount of debt issues in forint by 2016. Extreme values of the distribution are consistent with past observations.

Histogram of r.2012

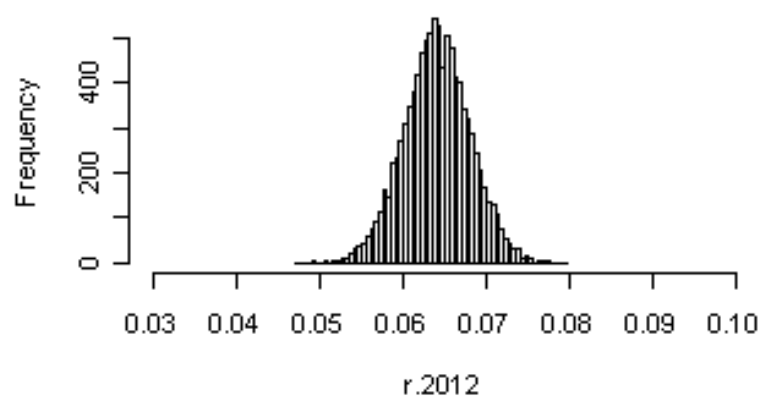

Histogram of r.2014

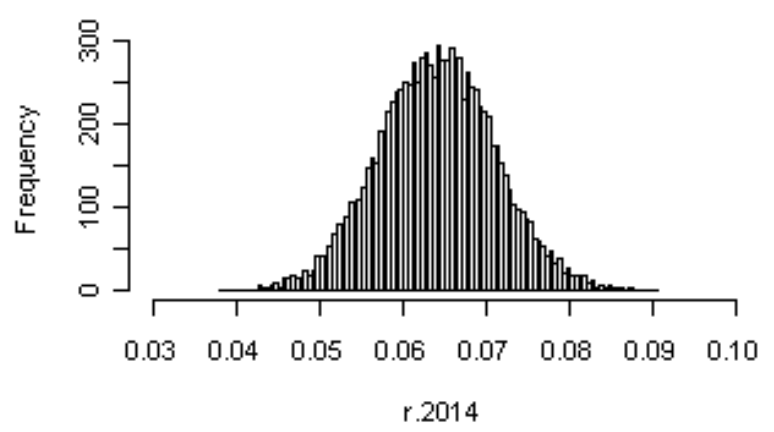

Histogram of r.2016

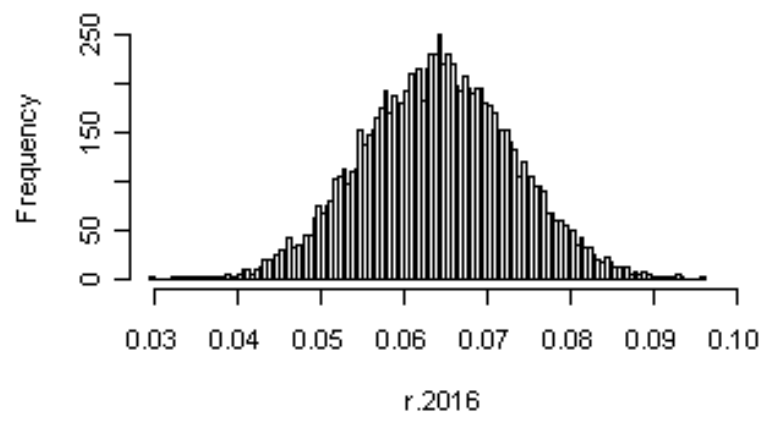

Histogram of r.2013

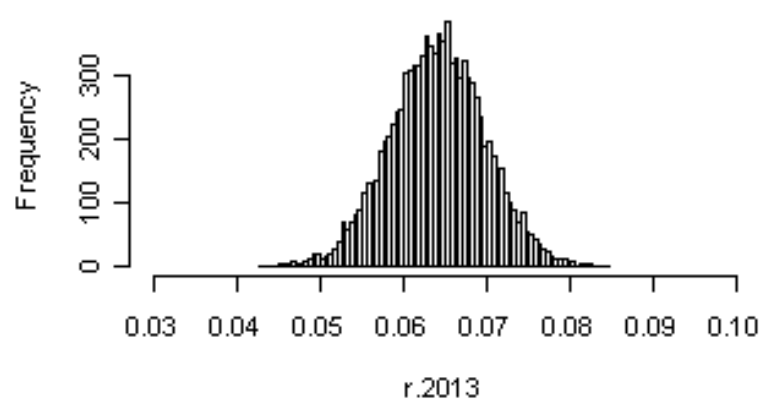

Histogram of r.2015

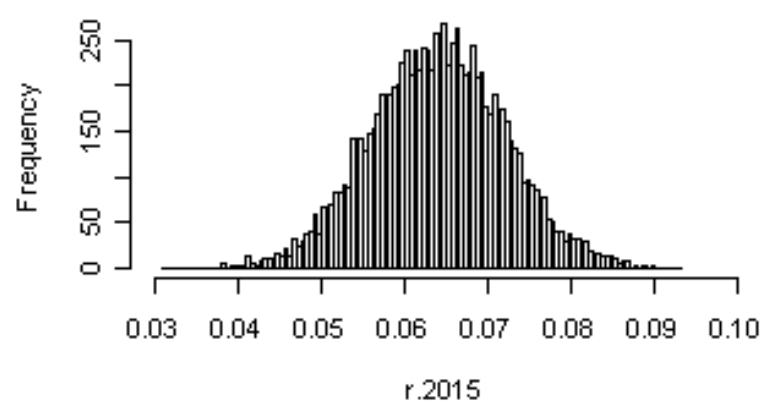




\section{Permanent shocks}

With permanent shocks, interest rates take more extreme value not experienced in the past. Notably, interest rates hit increasingly the zero bound while highest values go beyond $15 \%$. However, values with the $50 \%$ probability seem plausible and those within the $95 \%$ interval could belong to some extreme, although less likely scenarios.

Histogram of r.2012

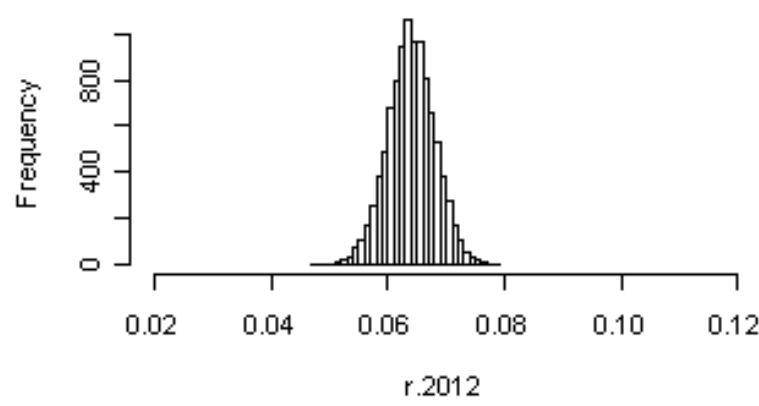

Histogram of r.2014

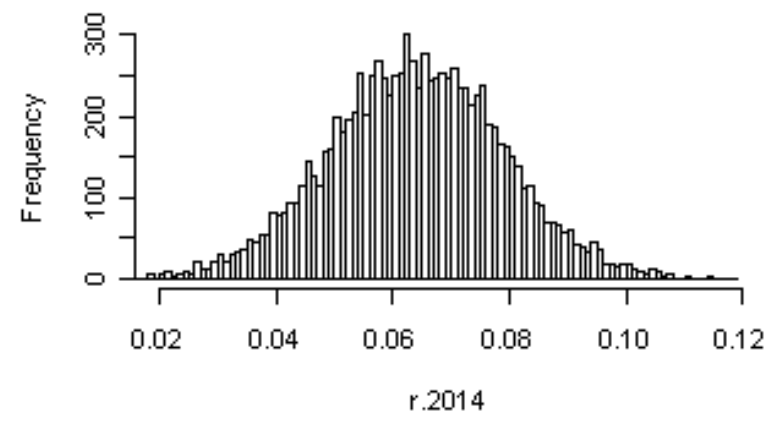

Histogram of r.2016

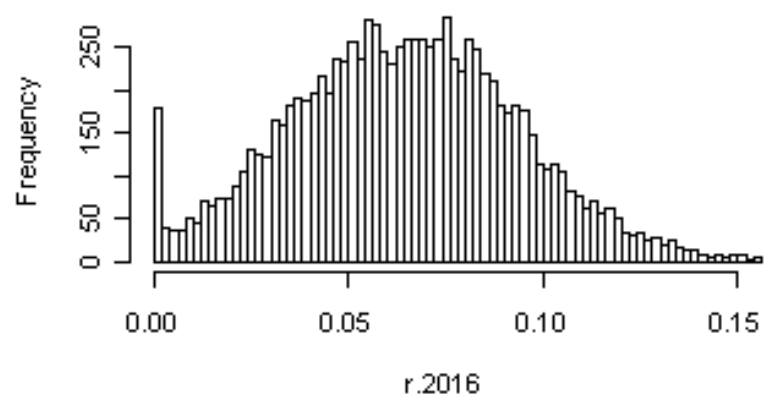

Histogram of r.2013

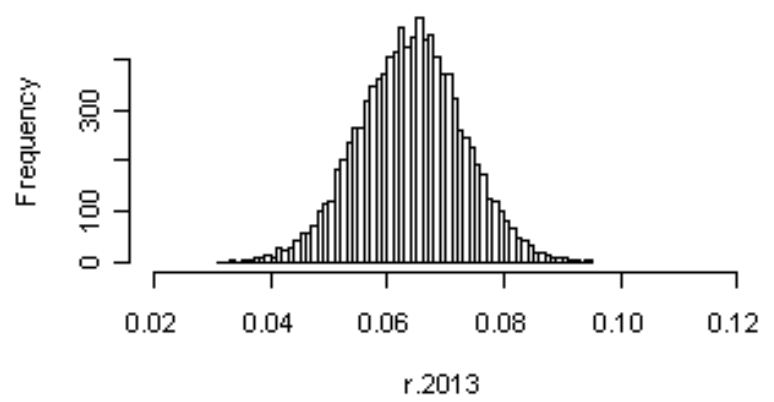

Histogram of r.2015

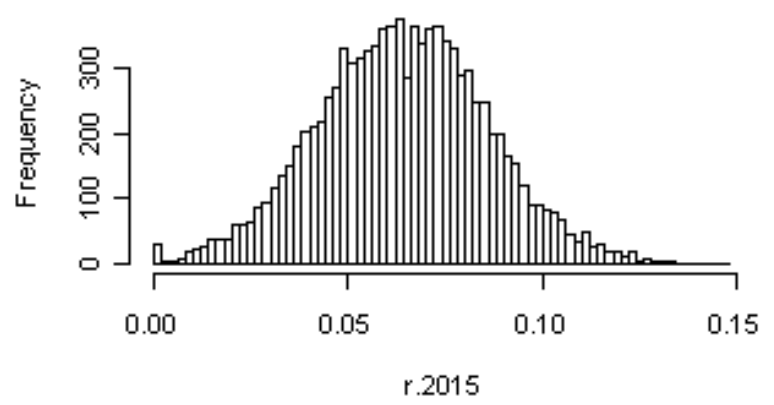


ECO/WKP(2012)23

\section{Distribution of interest rates in euro}

Temporary shocks

The distribution of interest rate in euro is widening more slowly than in forint as the debt is fully rolled over only after 10 years. Extreme values of the distribution are consistent with past observations and highly plausible.
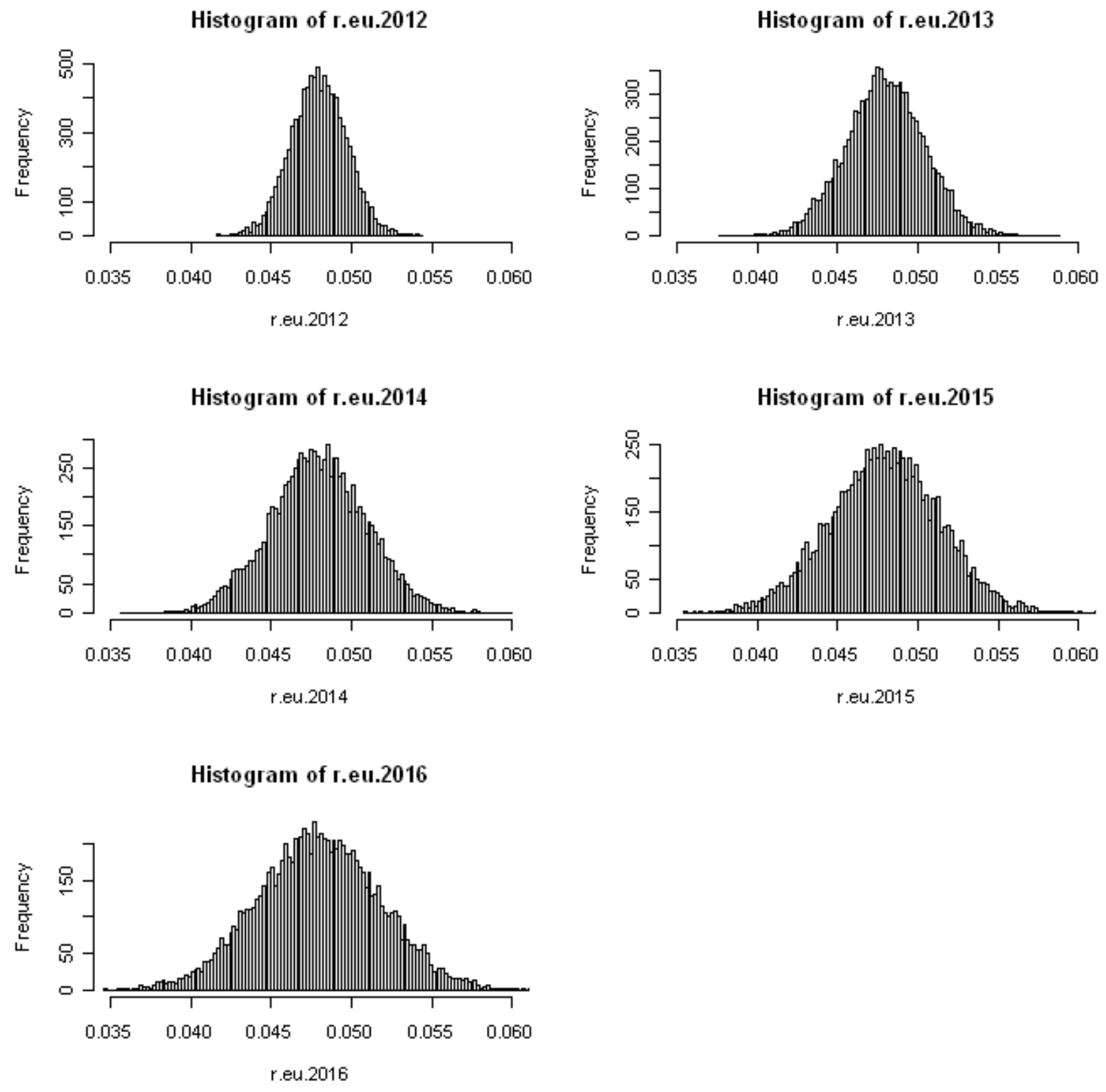


\section{Permanent shocks}

As for the forint, interest rates take more extreme value not experienced in the past in the permanent scenario. However, the zero bound is not hit as debt is rolled over more progressively and overall values within the $95 \%$ interval remain plausible.

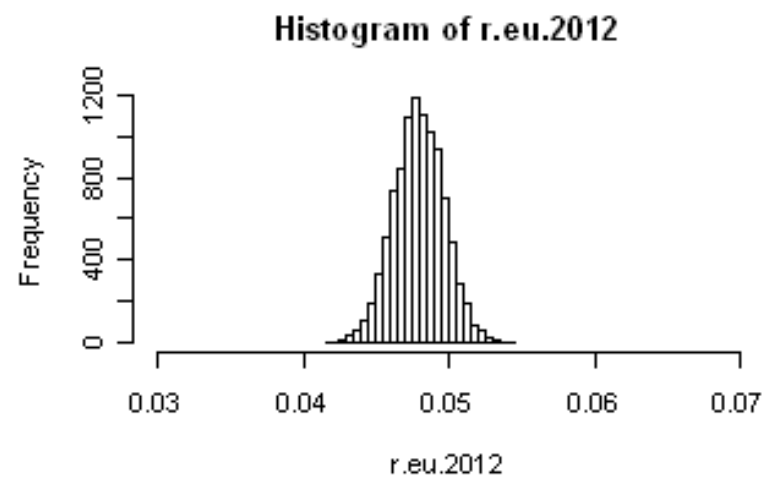

Histogram of r.eu.2014

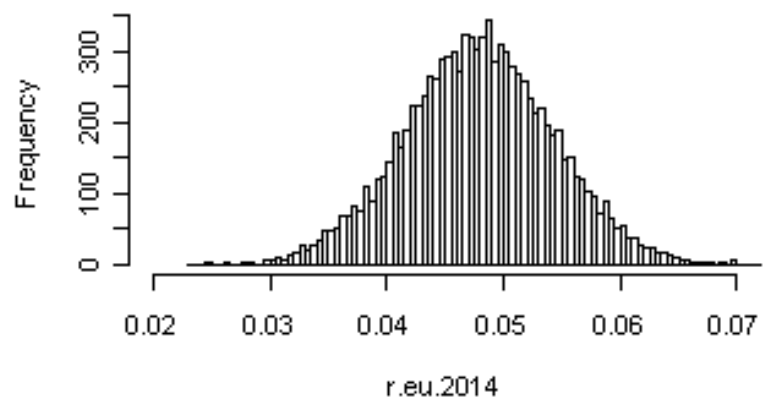

Histogram of r.eu.2016

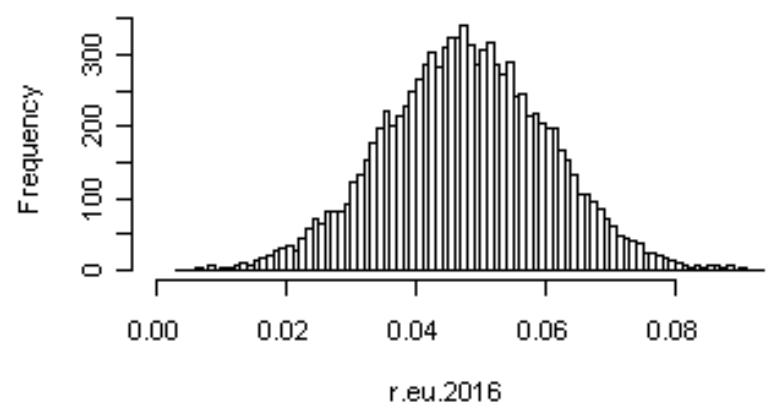

Histogram of r.eu.2013

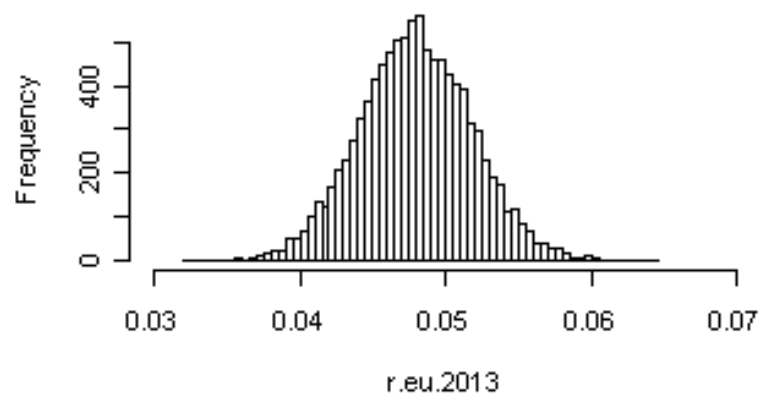

Histogram of r.eu.2015

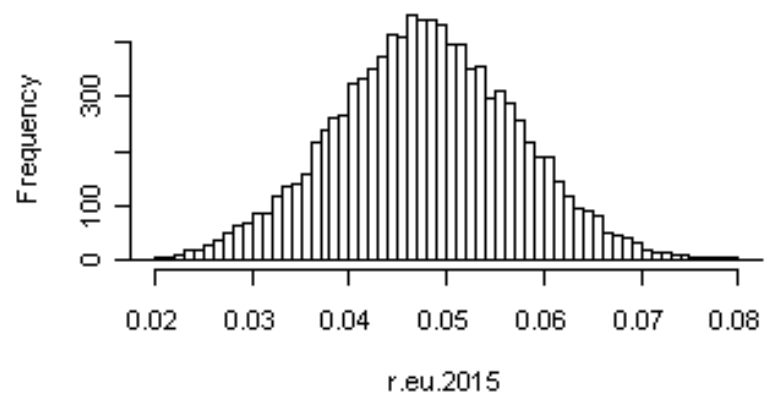




\section{WORKING PAPERS}

The full series of Economics Department Working Papers can be consulted at www.oecd.org/eco/workingpapers/

945. Non-Keynesian effects of fiscal consolidation: an analysis with an estimated DSGE Model for the Hungarian economy

(March 2012) by Szilárd Benk and Zoltán M. Jakab

944. Work incentives and recent reforms in tax and benefit system in Hungary

(March 2012) by Tímea Ladányi and Rafal Kierzenkowski

943. Building blocks for a better functioning housing market in Chile

(February 2012) by Aida Caldera Sánchez

942. The impact of changes in second pension pillars on public finances in Central and Eastern Europe (January 2012) by Balász Égert

941. Improving energy system efficiency in the Czech Republic (January 2012) by Artur Radziwill

940. Structural change and the current account: the case of Germany (January 2012) by Fabrizio Coricelli and Andreas Wörgötter

939. Reforming education in England

(January 2012) by Henrik Braconier

938. The nature of financial and real business cycles: The great moderation and banking sector procyclicality

(January 2012) by Balázs Égert and Douglas Sutherland

937. Fiscal consolidation

Part 6. What are the best policy instruments for fiscal consolidation?

(January 2012) by Robert P. Hagemann

936. Fiscal consolidation

Part 5. What factors determine the success of consolidation efforts?

(January 2012) by Margit Molnar

935. Fiscal consolidation

Part 4. Case studies of large fiscal consolidation episodes

(January 2012) by Hansjörg Blöchliger, Dae-Ho Song and Douglas Sutherland

934. Fiscal consolidation

Part 3. Long-run projections and fiscal gap calculations

(January 2012) by Rossana Merola and Douglas Sutherland

933. Fiscal consolidation

Part 2. Fiscal multipliers and fiscal consolidations

(forthcoming) by Ray Barrell, Dawn Holland and Ian Hurst 
932. Fiscal consolidation

Part 1. How much is needed and how to reduce debt to a prudent level?

(January 2012) by Douglas Sutherland, Peter Hoeller and Rossana Merola

931. Less income inequality and more growth - Are they compatible?

Part 8. The drivers of labour income inequality - A review of the recent literature

(forthcoming) by Rafal Kierzenkowski and Isabell Koske

930. Less income inequality and more growth - Are they compatible?

Part 7. The drivers of labour earnings inequality - An analysis based on conditional and unconditional quantile regressions

(January 2012) by Jean-Marc Fournier and Isabell Koske

929. Less income inequality and more growth - Are they compatible?

Part 6. The distribution of wealth

(January 2012) by Kaja Bonesmo Fredriksen

928. Less income inequality and more growth - Are they compatible?

Part 5. Poverty in OECD countries

(January 2012) by Mauro Pisu

927. Less income inequality and more growth - Are they compatible?

Part 4. Top incomes

(January 2012) by Peter Hoeller

926. Less income inequality and more growth - Are they compatible?

Part 3. Income redistribution via taxes and transfers across OECD countries

(January 2012) by Isabelle Joumard, Mauro Pisu and Debbie Bloch

925. Less income inequality and more growth - Are they compatible?

Part 2. The distribution of labour income

(January 2012) by Isabell Koske, Jean-Marc Fournier and Isabelle Wanner

924. Less income inequality and more growth - Are they compatible?

Part 1. Mapping income inequality across the OECD

(January 2012) by Peter Hoeller, Isabelle Joumard, Mauro Pisu and Debbie Bloch

923. Current issues in managing government debt and assets

(December 2011) by Eckhard Wurzel and Lukasz Rawdanowicz

922. Public spending efficiency in the Czech Republic: fiscal policy framework and the main spending areas of pensions and healthcare

(December 2011) by Zuzana Smidova

921. Exploring determinants of subjective wellbeing in OECD countries - evidence from the World Value Survey

(December 2011) by Sarah Fleche, Conal Smith and Piritta Sorsa

920. Russia: progress in structural reform and framework conditions

(December 2011) by Yana Vaziakova, Geoff Barnard and Tatiana Lysenko 